\title{
PENGARUH KONSELING GOAL SETTING TERHADAP PENINGKATAN MOTIVASI KARYAWAN
}

\section{THE IMPACT OF GOAL-SETTING COUNSELING TO IMPROVE EMPLOYEE'S MOTIVATION}

\author{
Nidya Paramita \\ Arief Fahmie \\ Fakultas Psikologi dan Ilmu Sosial Budaya Universitas Islam Indonesia Yogyakarta \\ Email: nidyaparamita22@yahoo.co.id; a.fahmie@uii.ac.id
}

\begin{abstract}
This study aimed to examine the effect of counseling focuses on goal-setting to motivate the employees. The hypothesis is there is the samples were 16 supervisors who had a low score of motivation. The design used is a true experiment with a pretest-posttest control group design. The data analysis techniques used was nonparametric analysis of Mann-Whitney test. The results showed that the scale of significance of motivation in the experimental group $=0.02(p<0.05)$ this means that there is significant difference on the level of motivation of the experimental group between before and after a given treatment form of counseling focuses on goal setting.
\end{abstract}

Key words: Group counseling, goal-setting, motivation

\begin{abstract}
ABSTRAK
Penelitian ini bertujuan melihat pengaruh konseling berfokus pada penetapan tujuan dalam meningkatkan motivasi pada karyawan. Hipotesis yang diajukan adalah terdapat pengaruh positif pemberian konseling berfokus pada penetapan tujuan terhadap peningkatan motivasi pada karyawan. Sampel terdiri 16 orang level pengawas yang memiliki nilai skor motivasi rendah dan sedang. Rancangan yang digunakan adalah true experiment dengan pretest-posttest control group design. Teknik analisis yang digunakan adalah analisis non parametric uji Mann-Whitney Test. Hasil analisis menunjukan nilai signifikansi skala motivasi pada kelompok eksperimen sebesar $=0,02(p<0,05)$ yang berarti terdapat perbedaan signifikan terhadap tingkat motivasi pada kelompok eksperimen antara sebelum dan setelah diberikan perlakuan berupa konseling berfokus pada penetapan tujuan.
\end{abstract}

Kata kunci: Konseling kelompok, penetapan tujuan, motivasi kerja

Penelitian ini dilatarbelakangi pandangan bahwa karyawan adalah aset perusahaan yang penting dan perlu dikelola serta dikembangkan untuk mendukung keberlangsungan perusahaan itu sendiri. Perusahaan perlu menciptakan lingkung- an yang kondusif, imbalan yang layak dan adil, beban kerja yang sesuai dengan keahlian karyawan, sikap dan perilaku dari manajer guna peningkatan motivasi karyawan yang akan mendukung tercapainya tujuan organisasi. 
Motivasi seorang pegawai untuk bekerja biasanya ditunjukan oleh aktivitas yang terus menerus dan yang berorientasi tujuan. Pegawai yang bermotivasi tinggi adalah pegawai yang perilakunya diarahkan kepada tujuan organisasi dan aktivitas-aktivitasnya tidak mudah terganggu oleh gangguan-gangguan kecil (Gomes, 2003). Adapun ciri-ciri karyawan yang memiliki motivasi kerja tinggi menurut Gomes (2003) adalah mampu bersaing dalam berprestasi, ingin segera mengetahui hasil kongkrit dari usaha yang dilakukan, tingkat aspirasi menengah, berorientasi ke masa yang akan datang, tidak suka membuang-buang waktu, mempunyai rasa tanggung jawab, percaya diri, dan ulet dalam menjalankan tugas.

Gomes (2003) juga menjelaskan pegawai yang tidak bermotivasi tinggi adalah karyawan yang memiliki ciri-ciri seperti perilaku pegawai tidak memperlihatkan goal directed (berorientasikan tujuan), perilaku pegawai tidak diarahkan pada tujuan yang bernilai bagi organisasi, dan pegawai tidak berkomitmen terhadap tujuan, dan karenanya jadi mudah terganggu sehingga menuntut adanya pengawasan yang tinggi dari atasan.

Problem di atas tampaknya terjadi pada sebuah perusahaan yang bernama PT SM. Pada awalnya perusahaan ini dikelola dengan sistem manajemen keluarga. Adanya keinginan serta peluang bagi perusahaan untuk berkembang. Manajemen kekeluargaan dianggap sudah tidak mampu lagi mengakomodasi perkembangan zaman dalam upaya peme- nuhan permintaan pasar. Selain itu, juga banyaknya perusahaan sejenis yang bermunculan menjadi kompetitor di bidang yang sama dengan jenis produk yang lebih variatif, sehingga pada tahun 2002 PT SM mulai beralih menuju sistem manajemen profesional yang mampu memberikan pelayanan dan kerja sama yang baik kepada stakeholder-nya.

Berdasarkan hasil asesmen awal yang dilakukan pada 17 pengawas di PT SM dengan menggunakan indikator motivasi rendah menurut Gomes (2003) diketahui terdapat lima pengawas yang memiliki nilai skala motivasi yang rendah, sedangkan 12 orang pengawas lainnya memiliki nilai skala motivasi sedang. Hal ini juga didukung dengan grafik hasil pencapaian produksi periode Oktober 2012 sampai April 2013 dan wawancara yang dilakukan dengan pihak HRD.

Berdasarkan wawancara yang dilakukan dengan pihak HRD, permasalahan yang muncul pada level foreman antara lain target produksi yang ditetapkan oleh perusahaan sering tidak dapat terpenuhi. Padahal pada setiap line telah ditetapkan jumlah produk yang harus dihasilkan untuk memenuhi dan mencukupi target produksi. Pengawas memegang peranan penting pada kondisi tersebut karena memiliki tanggung jawab terhadap pengaturan dan pengawasan terhadap line yang dipimpinnya. Karenanya, diperlukan pengawas yang memiliki motivasi yang baik untuk dapat memenuhi target-target yang dibebankan oleh perusahaan dan 
untuk menghadapi kendala-kendala yang ada di lapangan.

Konseling yang berfokus pada penetapan tujuan tidak hanya memberikan pengaruh pada pekerjaan karyawan, tetapi juga mendorong karyawan itu sendiri untuk mencari dan menggunakan metode kerja yang paling efektif dan dengan melibatkan karyawan dalam menetapkan tujuan dapat menumbuhkan motivasi kerja dan prestasi kerja yang maksimal (Steers, Porter, \& Bigley, 1996).

Layanan konseling berfokus penetapan tujuan ini juga dimaksudkan untuk memperhatikan kesejahteraan para karyawan, karena manusia merupakan salah satu komponen utama dalam industri. Kualitas dan kesejahteraan karyawan dalam suatu industri sangat menentukan kemajuan dan produktivitas industri tersebut (Carroll, 1996). Meskipun konseling dirasakan sebagai suatu kebutuhan di dunia industri, namun kenyataan menunjukkan bahwa belum banyak industri yang secara eksplisit mencanangkan layanan konseling dengan konselor profesional di suatu perusahaan (Renddy, 1993).

Melalui layanan konseling yang berfokus pada penetapan tujuan diharapkan potensi karyawan dapat dikembangkan dan dimanfaatkan secara optimal, iklim kerja yang kondusif dapat diciptakan, serta berbagai perasaan ketidakpastian yang sering manghantui kinerja karyawan dapat diantisipasi dan di atasi (Carroll, 1996). Sumber daya manusia pada bidang industri (di antaranya para karyawan) sebagai human capital perlu ditata pengembangan karirnya, perlu difasilitasi perkembangan potensinya, serta perlu diperhatikan kesejahteraan fisik dan psikisnya (Walgito, 2005). Layanan konseling yang berfokus pada penetapan tujuan di dunia industri diharapkan mampu mengembangkan fungsi-fungsi tersebut.

Dalam dunia industri, konseling lebih dimaknai sebagai proses membantu individu dalam proses penyelesaian masalah (assisting people in the process of problem solving) (Walgito, 2005). Termasuk di dalamnya pengertian konseling adalah membantu karyawan bagaimana memutuskan suatu permasalahan yang ada, bukan pula sekedar berbicara tentang apa yang harus dikerjakan seseorang, tetapi lebih dari itu yaitu memberikan asumsi-asumsi berkaitan persoalan yang sedang dihadapi oleh karyawan dan memberikan alternatif jalan keluar yang lebih sesuai (Renddy, 1993).

Dengan demikian, konseling yang berfokus pada penetapan tujuan merupakan strategi pemotivasian yang krusial dalam upaya peningkatan produktivitas dan sekaligus memotivasi karyawan untuk mencapai tujuan perusahaan. Melalui konseling karyawan dapat memperbaiki dan meningkatkan motivasi dan menghasilkan pekerjaan yang memuaskan bagi perusahaan.

Berdasarkan uraian di atas dapat disimpulkan bahwa konseling yang berfokus pada penetapan tujuan sangat penting dilakukan oleh pihak perusahaan untuk memfasilitasi peningkatan motivasi para karyawannya sehingga dapat memberikan 
pengaruh positif terhadap perusahaan khususnya terkait dengan pencapain target produksi. Dengan demikian, hipotesis yang diajukan adalah konseling yang berfokus pada penetapan tujuan efektif dalam meningkatkan motivasi kerja karyawan.

\section{METODE PENELITIAN}

\section{Desain Penelitian}

Desain penelitian ini adalah true experiment dengan pretest-posttest control group design, yaitu model penelitian eksperimen dengan menggunakan kelompok eksperimen dan kelompok kontrol. Pemilihan kelompok kontrol dan eksperimen dilakukan secara random. Kelompok eksperimen mendapatkan intervensi atau perlakukan berupa konseling yang berfokus pada penetapan tujuan, sedangkan pada kelompok kontrol hanya diberikan feedback dari hasil pengukuran tingkat motivasi yang telah dilakukan. Namun terlebih dahulu dilakukan pengukuran awal untuk melihat pengaruh intervensi yang diberikan sebelum dan setelah perlakuan.

\section{Subjek penelitian}

Subjek penelitian ini berjumlah 16 orang level pengawas pada PT SM yang memiliki nilai skor motivasi rendah dan sedang. Subjek tersebut dibagi dalam dua kelompok, yaitu kelompok kontrol dan kelompok eksperimen.

\section{Metode Pengumpulan Data}

Pengumpulan data dalam penelitian ini terdiri dari data primer dan data sekunder. Data primer adalah data langsung yang dikumpulkan dari obyek penelitian dan diperoleh dengan cara penyebaran kuesioner atau angket beraitem 40 pernyataan yang mengacu pada aspek motivasi teori Herzberg yaitu: responsibility, advancement, work it self, achievement, growth, dan recognition. Jumlah aitem yang lolos dari skala motivasi adalah 35 buah. Koefisien korelasi aitem-total bergerak antara 0,357 sampai dengan 0,801 . Sementara koefisien alpha adalah 0,952 .

Pengumpulan data selanjutnya yaitu dengan menggunakan pengumpulan dokumentasi. Data ini adalah data sekunder yang berfungsi sebagai data penunjang untuk menganalisis masalah dari sumber dalam perusahaan berupa struktur organisasi dan dokumentasi foto-foto pelaksanaan.

\section{Prosedur Pemberian Perlakuan}

Dalam penelitian ini kelompok eksperimen mendapatkan intervensi atau perlakukan berupa konseling yang berfokus pada penetapan tujuan. Terlebih dahulu masing-masing subjek pada kelompok eksperimen diminta untuk mengisi angket yang mengungkap atau mengukur tingkat motivasi subjek sebelum diberikan perlakuan (prates). Setelah diberikan prates, baru intervensi diberikan. Setelah perlakuan diberikan peneliti melakukan pascates. Pada kelompok kontrol tidak 
diberikan intervensi seperti pada kelompok eksperimen. Secara lebih rinci, berikut penjelasannya.

Pengukuran awal (prates). Pengukuran awal (prates) dilakukan pada hari Senin, 8 Juli 2013 dan dikembalikan ke peneliti pada hari Rabu, 10 Juli 2013. Sebelum karyawan mengikuti prates, peneliti meminta subjek untuk mengisi informed consent yang berisi tentang tujuan dan proses penelitian yang dilaksanakan serta kesediaannya mengikuti proses penelitian. Prates menggunakan skala motivasi Herzberg dengan memfokuskan pada aspek instrinsik. Aitem skala motivasi Herzberg terdiri dari 40 pertanyaan, dan peserta prates terdiri dari 7 orang karyawan pada level pengawas PT.SM.

Pelaksanaan intervensi. Peneliti memberikan intervensi atau perlakuan untuk mengatasi permasalahan dalam penelitian ini yang berupa konseling berfokus pada penetapan tujuan untuk meningkatkan motivasi karyawan. Konselor dalam intervensi ini adalah lbu Siti Solehah, S.Psi., M.Psi., Psikolog yang memandu semua tahapan dari konseling yang dilakukan. Konseling berfokus pada penetapan tujuan ini dilaksanakan dalam tiga kali pertemuan dengan setiap pertemuan konseling terbagi dalam tiga sesi. Pertemuan pertama: mengenali situasi dengan tiga sesi: cerita, kelemahan dan kelebihan, dan pengaruh. Pertemuan kedua: mengubah gambaran dengan tiga sesi: kemungkinan, agenda, dan komitmen. Pertemuan ketiga: mengimplementasikan tindakan dengan tiga sesi: strategi, pilihan terbaik, dan rencana tindakan. Pada sesi akhir pertemuan ini konselor bersama konseli membuat kesimpulan mengenai hasil proses konseling, menyusun rencana tindakan yang akan dilakukan berdasarkan kesepakatan yang telah terbangun dari proses konse-ling sebelumnya dan mengevaluasi jalan-nya proses dan hasil konseling secara keseluruhan.

Pengukuran Akhir (Pascates). Pelaksanaan pascates dilakukan pada hari yang sama setelah sesi terakhir konseling dilakukan. Pascates dilakukan pada tanggal 29 Juli 2013.

Pelaksanaan Tindak Lanjut (FollowUp). Pelaksanaan tindak lanjut dilakukan satu bulan setelah pelaksanaan konseling dengan memberkan kembali angket untuk diisi oleh subjek pada kelompok eksperimen.

Pelaksanaan Intervensi Kelompok Kontrol. Peneliti memberikan feedback kepada kelompok kontrol setelah rangkaian rancangan penelitian berakhir. Dengan kata lain, intervensi bagi kelompok kontrol bukan merupakan bagian rancangan penelitian, melainkan sebagai usaha untuk menjalankan etika penelitian. Pelaksanaan feedback bagi kelompok ini diberikan oleh konselor yang sama pada saat konseling bagi kelompok eksperimen. Feedback yang diberikan hanya penjelasan dan gambaran mengenai pentingnya karyawan untuk memiliki motivasi yang baik untuk mendukung tercapainya target perusahaan, dan dijelaskan juga langkah-langkah dalam proses 
penetapan tujuan, faktor apa aja yang memengaruhi penetapan tujuan dan tujuan-tujuan yang bagaimana yang mungkin untuk diterapkan.

\section{Teknik Analisis Data}

Teknik analisis data yang digunakan dalam penelitian ini adalah analisis non parametric karena jumlah sampelnya kecil (Ghozali \& Castellan, 2002). Pengujian perbedaan tingkat motivasi antara sebelum dan sesudah diberi intervensi antar kelompok menggunakan teknik analisis U-Mann Whitney, yaitu dengan memban- dingkan dua mean populasi sama atau tidak hasil dari kelompok eksperimen atau kelompok yang mendapat perlakuaan dengan kelompok kontrol yang tidak mendapat perlakuan (Sugiyono, 2007)

\section{HASIL PENELITIAN}

\section{Data Deskriptif}

Setelah melakukan proses pengambilan data, selanjutnya data dianalisis untuk mengetahui hasil dari penelitian yang telah dilakukan. Analisis data dilakukan dengan analisis deskriptif dan kuantitatif:

Tabel 1. Data Kategorisasi Kelompok Eksperimen Berdasar Skor Skala Motivasi

\begin{tabular}{ccccccc}
\hline Subjek Eksperimen & Prates & Kategori & Pascates & Kategori & Tindak Lanjut & Kategori \\
\hline S 1 & 100 & Sedang & 124 & Tinggi & 124 & Tinggi \\
S 2 & 102 & Sedang & 119 & Sedang & 117 & Sedang \\
S 3 & 100 & Sedang & 115 & Sedang & 113 & Sedang \\
S 4 & 95 & Sedang & 111 & Sedang & 107 & Sedang \\
S 5 & 86 & Rendah & 112 & Sedang & 111 & Sedang \\
S 6 & 87 & Rendah & 114 & Sedang & 110 & Sedang \\
S 7 & 83 & Sedang & 115 & Sedang & 115 & Sedang \\
\hline
\end{tabular}

Tabel 2. Data Kategorisasi Kelompok Kontrol Berdasar Skor Skala Motivasi

\begin{tabular}{ccccccc}
\hline Subjek Kontrol & Prates & Kategori & Pascates & Kategori & Tindak Lanjut & Kategori \\
\hline S 1 & 103 & Sedang & 92 & Sedang & 99 & Sedang \\
S 2 & 82 & Rendah & 80 & Rendah & 83 & Rendah \\
S 3 & 97 & Sedang & 105 & Sedang & 92 & Sedang \\
S 4 & 101 & Sedang & 91 & Sedang & 102 & Sedang \\
S 5 & 100 & Sedang & 91 & Sedang & 97 & Sedang \\
S 6 & 102 & Sedang & 101 & Sedang & 89 & Sedang \\
S 7 & 99 & Sedang & 94 & Sedang & 100 & Sedang \\
S 8 & 84 & Rendah & 85 & Rendah & 95 & Sedang \\
\hline
\end{tabular}




\section{Pengujian Hipotesis}

Pengujian hipotesis dalam penelitian ini menggunakan analisis MannWhitney Test. Analisis ini digunakan untuk mengetahui perbedaan pengaruh konseling berfokus pada penetapan tujuan terhadap peningkatan motivasi karyawan khususnya pada level pengawas di PT SM sebelum dan setelah diberikan perlakuan.

Hasil analisis uji Mann-Whitney skor prates pada kelompok eksperimen dan kelompok kontrol diperoleh $\mathrm{Z}=-0,523$ dan skor $p=0,601$ sehingga $p>0,05$. Berdasarkan analisis uji Mann-Whitney tersebut diketahui bahwa tidak ada perbedaan yang signifikan dalam hal tingkat motivasi pada kelompok eksperimen dan kontrol sebelum diberikan intervensi berupa konseling berfokus pada penetapan tujuan. Artinya tidak ada perbedaan tingkat motivasi antara kelompok eksperimen dengan kelompok kontrol sebelum konseling diberikan.

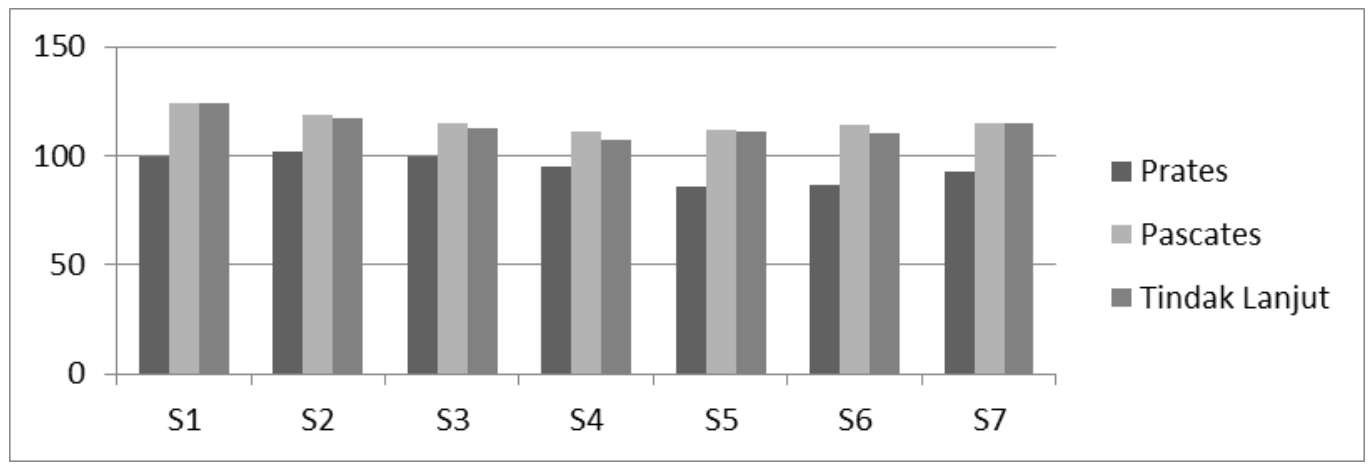

Gambar 1. Grafik Skor Subjek Kelompok Eksperimen Prates-Paskates-Tindak Lanjut Skala Motivasi Herzberg

Dari grafik di atas dapat dilihat perubahan tingkat motivasi pada masingmasing subjek kelompok eksperimen pada saat prates, pascates dan tindak lanjut. Pada subjek 1 pada saat prates skor yang didapat adalah 100 , pada saat pascates skor meningkat menjadi 124 dan pada tindak lanjut skot tetep pada angka 124. Pada subjek 2, skor prates sebesar 102, pada pascates mengalami peningkatan menjadi 119 dan skor 117 untuk tindak lanjut. Subjek 3, skor prates sebesar 100, pascates 115 dan 113 pada saat tindak lanjut. Subjek 4, skor prates sebesar 95, pada pascates mengalami peningkatan menjadi 111 dan 107 untuk skor tindak lanjut. Subjek 5 skor prates sebesar 86, pada pascates mengalami peningkatan menjadi 112 dan 111 untuk tindak lanjut. Subjek 6 nilai skor sebesar 87, pada pascates menjadi 114 dan 110 untuk tindak lanjut. Subjek 7 skor pratesnya adalah 93, pada pascates menjadi 115 dan tetap 115 untuk tindak lanjut. 


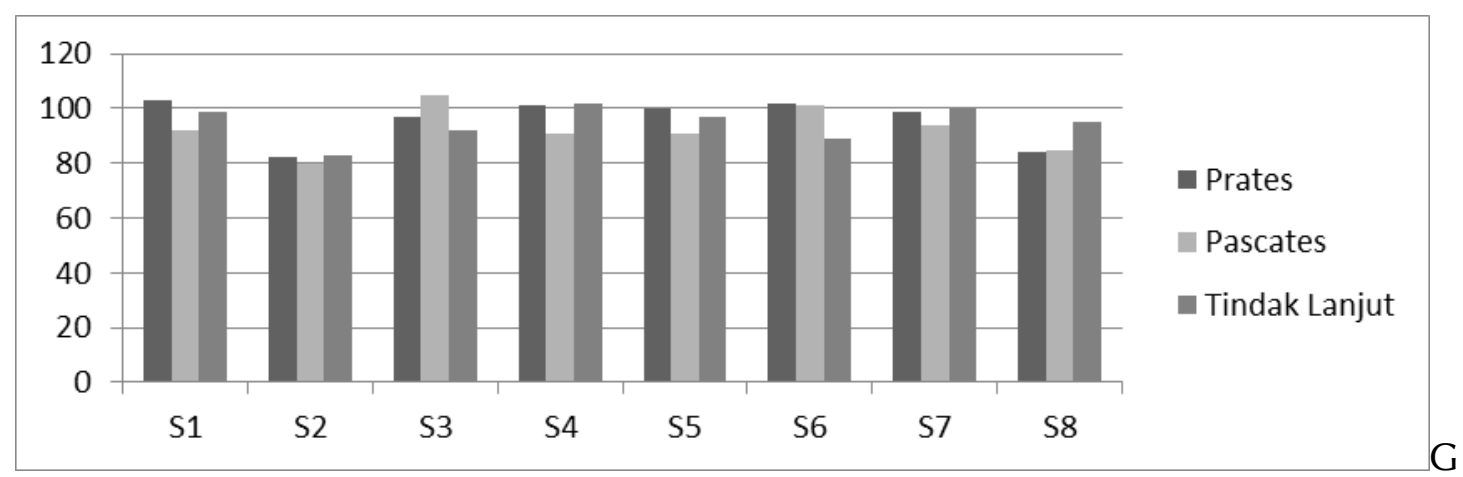

Gambar 2. Grafik Skor Subjek Kelompok Kontrol Prates-Paskates-Tindak Lanjut Skala Motivasi Herzberg

Pada grafik di atas dapat dilihat perubahan skor pada masing-masing subjek kelompok kontrol. Pada subjek 1 nilai prates adalah 103 kemudian menjadi 92 pada saat pascates dan 99 pada saat tindak lanjut. Subjek 2 nilai prates adalah 82 , pada saat pascates 80 dan menjadi 83 pada saat tindak lanjut. Subjek 3 nilai prates 97, meningkat menjadi 105 pada saat pascates dan 92 pada tindak lanjut. Subjek 4, skor prates adalah 101, pada pascates 91 dan pada tindak lanjut skornya adalah 102. Subjek 5 nilai prates 100, menjadi 91 pada saat pascates dan 97 saat tindak lanjut. Pada subjek 6 nilai prates adalah 102, menjadi 101 pada pascates dan 89 pada saat tindak lanjut. Pada subjek 7 nilai prates 99, pascates 94, dan 100 untuk nilai tindak lanjut. Pada subjek 8 , nilai prates adalah 84 , pascates 85 dan 95 untuk nilai tindak lanjut.

Tabel 3. Nilai Mean Skala Motivasi Herzberg Prates, Pascates dan Tindak Lanjut Kelompok Eksperimen-Kontrol

\begin{tabular}{lccc}
\hline \multirow{2}{*}{ Kelompok } & \multicolumn{3}{c}{ Nilai Mean } \\
\cline { 2 - 4 } Eksperimen & 4,00 & 11,00 & 6,57 \\
Kontrol & 9,56 & 7,44 & 9,31 \\
\hline
\end{tabular}

Tabel di atas menunjukkan bahwa terdapat peningkatan mean pada kelompok eksperimen. Sebelum dilakukan perlakuan, nilai mean pada kelompok eksperimen sebesar 4,00 sedangkan setelah diberikan perlakuan berupa konseling berfokus pada penetapan tujuan skor mean meningkat menjadi 11,00 dan
6,57 pada saat tindak lanjut. Sementara itu pada kelompok kontrol yang tidak diberikan perlakuan, tampak terjadi penurunan nilai pascates dimana skor mean pada saat prates adalah 9,56 menjadi 7,44 dan 9,31 pada saat tindak lanjut. 


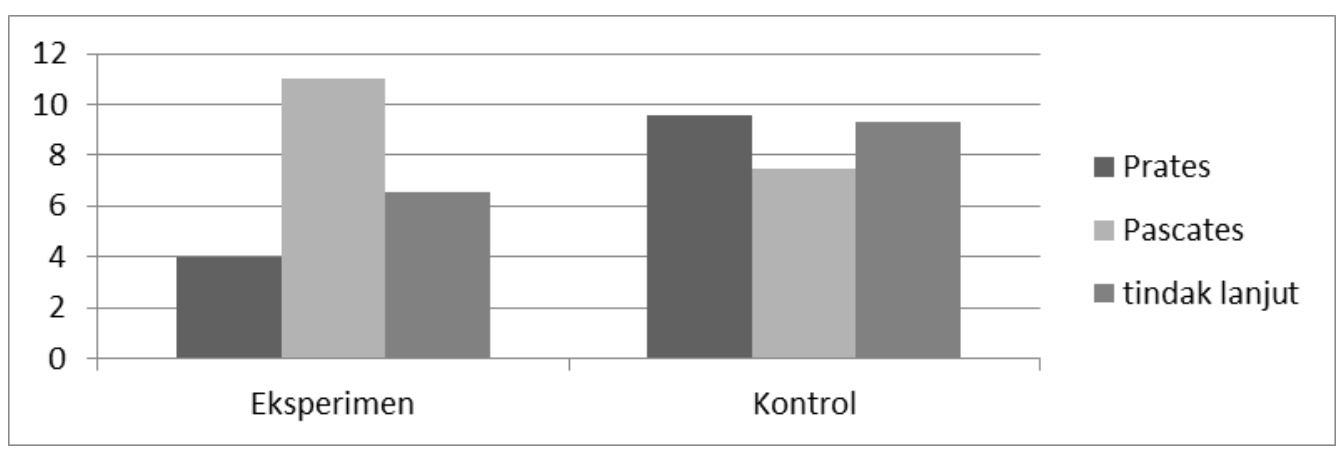

Gambar 3. Grafik Skor Mean Skala Motivasi Herzberg Prates, Pascates dan Tindak Lanjut Kelompok Eksperimen dan Kontrol

Analisis selanjutnya dilakukan de- kelompok eksperimen maupun kontrol. ngan menguji perbedaan antara skor Adapun hasil perhitungan uji beda kedua sebelum dan setelah perlakuan pada rata-rata adalah sebagai berikut:

Tabel 4. Uji Beda Skor Motivasi Herzberg Prates dan Pascates

\begin{tabular}{lccc}
\hline \multicolumn{1}{c}{ Kelompok } & $\mathbf{Z}$ & Nilai Probabilitas & Keterangan \\
\hline Eksperimen & -3.137 & .002 & Signifikan \\
Kontrol & -.894 & .371 & Tidak Signifikan \\
\hline
\end{tabular}

Tabel di atas menunjukkan bahwa pada kelompok eksperimen diperoleh nilai $z$ sebesar -3,137 dengan nilai probabilitas $p=0,02$ dengan taraf signifikan $5 \%$ menggunakan perhitungan statistik uji mann-whitney. Hal ini berarti $p<0,05$, menunjukkan bahwa pada kelompok eksperimen telah terjadi peningkatan skor motivasi pada level pengawas sebelum dan setelah diberikan intervensi berupa konseling berfokus pada penetapan tujuan. Namun hal yang berbeda terjadi pada kelompok kontrol, di mana nilai $z$ adalah $-0,894$ dengan nilai probabilitas $p=$ 0,371 . Hal ini berarti $p>0,05$, dengan taraf signifikan $5 \%$ yang menunjukkan bahwa pada kelompok kontrol tidak terjadi peningkatan pada skor motivasi.

Tabel 5. Uji Beda Skor Motivasi Herzberg Pascates dan Tindak Lanjut

\begin{tabular}{lccc}
\hline \multicolumn{1}{c}{ Kelompok } & $\mathbf{Z}$ & Nilai Probabilitas & Keterangan \\
\hline Eksperimen & -.836 & .403 & Tidak Signifikan \\
Kontrol & -.684 & .494 & Tidak Signifikan \\
\hline
\end{tabular}

Tabel di atas menunjukkan bahwa pada kelompok eksperimen diperoleh nilai z sebesar -0,836 dengan nilai proba- bilitas $p=0,403$ dengan taraf signifikan $5 \%$ menggunakan perhitungan statistic uji Mann-Whitney. Hal ini berarti $p<0,05$, 
menunjukkan bahwa pada kelompok eksperimen tidak terjadi perubahan motivasi pada level pengawas sebelum dan setelah diberikan intervensi berupa konseling berfokus pada penetapan tujuan. Hal yang sama terjadi pada kelompok kontrol, di mana nilai $z$ adalah $-0,684$ dengan nilai probabilitas $p=0,494$. Hal ini berarti $p$ $>0,05$, dengan taraf signifikan $5 \%$ yang menunjukkan bahwa pada kelompok kontrol tidak terjadi peningkatan pada skor motivasi.

Hasil tersebut menunjukkan bahwa pada kelompok eksperimen, subjek yang mendapatkan intervensi dapat mempertahankan kondisinya walaupun intrevensi yang diberikan telah satu bulan berlalu dan pada saat tindak lanjut diberikan kondisi peserta masih sama dengan setelah intervensi diberikan. Sedangkan pada kelompok kontrol tidak mengalami perubahan yang berarti pada saat dilakukan prates, pascates hingga tindak lanjut dilakukan. Hal tersebut dapat diartikan bahwa lingkungan kerja di PT SM relatif stabil dan tidak dapat meningkatkan motivasi para karyawan. Hal tersebut juga menunjukkan bahwa faktor intrinsik memberikan pengaruh yang cukup besar terhadap tingkat motivasi karyawan sehingga diperlukan intervensi yang difokuskan pada faktor-faktor yang bersifat intrinsik. Dengan demikian, dapat disimpulkan bahwa intervensi berupa konseling berfokus pada penetapan tujuan yang telah diberikan memang dibutuhkan oleh karyawan sebagai salah satu bentuk perlakuan yang da- pat digunakan untuk dapat meningkatkan motivasi karyawan di PT SM.

\section{PEMBAHASAN}

Fokus utama yang diteliti dalam penelitian ini adalah apakah konseling berfokus pada penetapan tujuan memiliki pengaruh dalam meningkatan motivasi pada karyawan di PT SM. Hipotesis yang diajukan adalah terdapat pengaruh positif pemberian konseling befokus pada penetapan tujuan terhadap peningkatan motivasi pada karyawan.

Analisis data prates dan pascates menggunakan uji non parametrik MannWhitney test dengan melakukan perhitungan skor motivasi antara kelompok eksperimen dan kelompok kontrol dengan melihat nilai mean masing-masing kelompok. Hasil analisis menunjukkan pada kelompok eksperimen diketahui nilai mean prates sebesar 4,00 dan pada kelompok kontrol sebesar 9,56. Kemudian setelah diberikan perlakuan berupa konseling kelompok berfokus pada penetapan tujuan terjadi peningkatan mean pascates pada kelompok eksperimen menjadi 11,00 , sementara pada kelompok kontrol tidak terjadi peningkatan dan bahkan terjadi penurunan mean menjadi 7,44 .

Selanjutnya analisis dilakukan untuk mengetahui apakah ada peningkatan skor motivasi sebelum dan setelah perlakuan pada kedua kelompok. Dari hasil analisis data yang dilakukan diketahui bahwa ada perbedaan antara skor prates dan skor 
pascates skala motivasi Herzberg pada kedua kelompok. Hal ini dapat diketahui dengan meilihat nilai $z$ pada kelompok eksperimen sebesar $-3,137$ dengan nilai probabilitas sebesar $0,02(p<0,05)$. Hasil tersebut menunjukkan bahwa pada kelompok eksperimen telah terjadi peningkatan skor motivasi pada level pengawas di PT SM sebelum dan setelah diberikan intervensi berupa konseling berfokus pada penetapan tujuan. Namun hal yang berbeda terjadi pada kelompok kontrol, di mana nilai $z$ adalah $-0,894$ dengan nilai proba-bilitas $0,371 \quad(p<0,05)$. Hal ini berarti bahwa $p>0,05$ pada kelompok kontrol tidak terjadi peningkatan pada skor moti-vasi pada level pengawas di PT SM.

Sedangkan pada skor pascates dan skor tindak lanjut skala motivasi Herzberg pada kedua kelompok dengan meilihat nilai $z$ pada kelompok eksperimen sebesar 0,403 dengan nilai probabilitas sebesar $-0,836(p<0,05)$. Hasil tersebut menunjukkan bahwa pada kelompok eksperimen tidak terjadi perubahan skor motivasi pada level pengawas di PT SM setelah diberikan perlakuan sampai satu bulan setelah perlakuan diberikan oleh peneliti. Hal yang berbeda terjadi pada kelompok kontrol, di mana nilai $z$ adalah $-0,684$ dengan nilai probabilitas $0,494(p>0,05)$. Hal ini berarti bahwa $p>0,05$ pada kelompok kontrol tidak terjadi peningkatan pada skor motivasi pada level pengawas di PT SM .

Hasil tersebut menunjukkan bahwa pada kelompok eksperimen subjek yang mendapatkan intervensi dapat mempertahankan kondisinya walaupun intervensi yang diberikan telah satu bulan berlalu dan pada saat tindak lanjut diberikan kondisi peserta masih sama dengan setalah intervensi diberikan. Sedangkan kelompok kontrol tidak mengalami perubahan yang berarti dari pada saat dilakukan prates, pascates hingga tindak lanjut dilakukan. Hal tersebut dapat diartikan bahwa lingkungan kerja di PT SM relatif stabil dan tidak dapat meningkatkan motivasi para karyawan. Hal tersebut juga menunjukkan bahwa faktor intrinsik memberikan pengaruh yang cukup besar terhadap tingkat motivasi karyawan sehingga diperlukan intervensi yang difokuskan pada faktor-faktor yang bersifat intrinsik. Dengan demikian dapat disimpulkan bahwa intervensi berupa konseling berfokus pada penetapan tujuan yang telah diberikan memang dibutuhkan oleh karyawan sebagai salah satu bentuk perlakuan yang dapat digunakan untuk dapat meningkatkan motivasi karyawan di PT SM .

Berdasarkan hasil yang telah dijelaskan di atas dapat disimpulkan bahwa Ho diterima yaitu terdapat pengaruh konseling kelompok yang berfokus pada penetapan tujuan terhadap peningkatan motivasi pada level pengawas di PT SM. Hal ini juga dapat mengindikasikan dan menunjukkan bahwa proses konseling yang telah dilakukan berlangsung dengan baik.

Dalam organisasi tentunya banyak faktor yang memengaruhi seseorang un- 
tuk mencapai tujuan yang telah ditetapkan, sedangkan jalannya organisasi atau perusahaan tentunya diwarnai oleh perilaku individu yang merasa berkepentingan dalam kelompoknya masing-masing. Perilaku individu yang berada dalam organisasi atau perusahaan tentunya sangat memengaruhi organisasi baik secara langsung maupun tidak langsung. Hal ini akibat adanya kemampuan individu yang berbeda-beda dalam menghadapi tugas atau aktivitasnya.

Menurut Walgito (2004), manfaat dilakukannya konseling kepada karyawan antara lain untuk meningkatkan produktivitas, mengikat karyawan, memberi tanda pada atasan tentang masalah yang terjadi sehubungan dengan organisasi, meningkatkan efisiensi usaha, dapat mengurangi terjadinya konflik dan mendorong kerjasama tim, mengantisipasi dan mencegah timbulnya masalah, memantapkan kemampuan untuk mengambil keputusan (bagi atasan, meningkatkan kesempatan berkarier, meningkatkan percaya diri dan kepuasan kerja. Konseling kerja dilakukan agar karyawan dapat mengetahui kelemahan dan kelebihan yang dimilikinya, terutama dalam hal yang berkaitan dengan pekerjaannya sehingga karyawan tersebut dapat memperbaiki kelemahannya dan terus meningkatkan kelebihannya. Karyawan yang mengetahui keadaan dirinya tersebut akan lebih mudah untuk melakukan penyesuaian diri dengan pekerjaannya.

Motivasi terbentuk dari sikap (attitude) seorang pegawai dalam menghadapi situasi kerja. Motivasi merupakan kondisi yang menggerakkan diri pegawai yang terarah untuk mencapai tujuan organisasi. Sementara itu sikap mental merupakan kondisi mental yang mendorong diri pegawai untuk berusaha mencapai prestasi kerja yang maksimal (Hasibuan, 2008). Telah mampunya subjek pada kelompok eksperimen dalam meningkatkan motivasi intrinsiknya sebagai usaha untuk mendukung tercapainya target perubahaan mengindikasikan bahwa karyawan memerlukan dorongan baik dari dalam dirinya sendiri maupun dari luar dan langkah-langkah yang lebih spesifik dalam proses pencapaian tujuan.

Timpe (2000) menjelaskan faktorfaktor internal yang memengaruhi motivasi individu antara lain: (1) Individu dengan segala unsur-unsurnya: kemampuan dan ketrampilan, kebiasaan, sikap dan sistem nilai yang dianut, pengalaman traumatis, latar belakang kehidupan sosial budaya, tingkat kedewasaan, (2) Situasi di mana individu bekerja akan menimbulkan berbagai rangsangan: persepsi individu terhadap kerja, harapan dan cita-cita dalam kerja itu sendiri, persepsi bagaimana kecakapannya terhadap kerja, kemungkinan timbulnya perasaan cemas, perasaan bahagia yang disebabkan oleh pekerjaan, (3) Proses penyesuaian yang harus dilakukan oleh masing-masing individu terhadap pelaksanaan pekerjaannya, (4) Pengaruh yang datang dari berbagai pihak: penga-ruh dari sesama rekan, kehidupan kelompok maupun tuntutan atau keinginan kepentingan keluar- 
ga, pengaruh dari berbagai hubungan di luar pekerjaan, (5) Timbulnya persepsi dan bangkitnya kebutuhan baru, cita-cita dan tujuan.

Budaya yang dimiliki oleh organisasi juga turut memberikan pengaruh pada SDM yang ada di perusahaan dalam penetapan tujuan individu dan penetapan tujuan organisasi itu sendiri. Budaya organisasi menggambarkan kesesuaian perilaku, mengikat dan memotivasi individu dan memberikan solusi/pemecahan apabila terdapat ambiguitas. Budaya mengatur jalannya proses informasi suatu perusahaan, hubungan internalnya dan nilai-nilai yang dianutnya (Robbins, 2009). Seperti halnya budaya yang dikembangkan di PT SM, yaitu etos kerja tinggi, gerakan untuk bekerja sama dan saling menghargai, aktif dalam pengembangan berkesinambungan untuk mencapai yang terbaik, semangat membangun budaya kesehatan dan keselamatan kerja, dan menjunjung kepedulian terhadap lingkungan dan masyarakat.

PT SM yang awalnya didirikan dengan manajemen kekeluargaan sedikit banyak memberikan pengaruh pada sistem kerja yang mengutamakan kekeluargaan namun tetap mengedepankan profesionalitas. Hal tersebut juga memberikan pengaruh yang besar pada proses dalam penetapan tujuan individu dan organisasi. Robbins (2009) juga menya-takan bahwa budaya organisasi merupa-kan gabungan dari sistem makna, nilai-nilai dan kepercayaan yang dianut bersama dalam suatu organisasi yang menjadi rujukan untuk bertindak dan membedakan organisasi satu dengan organisasi lain. Oleh karena itu, dalam proses penetapan tujuan juga harus dipertimbangkan aspek-aspek dari budaya organisasi yang telah dianut dan dijalankan oleh PT SM .

Motivasi adalah daya pendorong yang mengakibatkan seseorang atau organisasi mau dan rela untuk mengarahkan kemampuannya dalam bentuk keahlian atau keterampilan, tenaga dan juga waktunya untuk menyelenggarakan berbagai kegiatan yang menjadi tanggung jawabnya dan menunaikan kewajibannya dalam rangka pencapaian tujuan dan berbagai sarana organisasi yang telah ditentukan sebelumya (Hasibuan 2008).

Meningkatkatnya motivasi subjek pada kelompok eksperimen berdasarkan penjelasan teori yang ada dapat dikaitkan dengan beberapa hal, antara lain adanya keterbukaan dan penerimaan dari subjek untuk mengeluarkan dan menerima pendapat selama proses konseling berlangsung. Ketertarikan mereka untuk mempelajari sesuatu yang baru dan adanya bantuan dan dukungan dari pihak perusahaan untuk memfasilitasi kebutuhan pengembangan kompetensi dan peningkatan motivasi karyawan di PT SM juga turut membantu dan memengaruhi keberhasilan pelaksanaan proses konseling yang dilakukan. Pelaksanaan konseling yang difokuskan pada satu level yang sama, yaitu level pengawas juga memberikan pengaruh positif terhadap peningkatan motivasi karyawan karena mereka mendapatkan pemahaman yang sama sehingga dapat 
saling membantu antar sesama rekan kerja khususnya yang menjadi subjek dalam penelitian ini.

Berdasarkan survei yang dilakukan oleh Friey (2006) terhadap 6.000 karyawan di Inggris yang pernah mengikuti program EAPs, diperoleh hasil bahwa ada beberapa alasan utama mereka untuk menggunakan layanan konseling yang disediakan oleh perusahaan tempat mereka bekerja. Beberapa alasan tersebut antara lain adalah para karyawan tersebut merasa memiliki permasalahan pada hubungan pribadi, kesehatan, pekerjaan atau karir, dan keluarga (Athanasiades, Winthrop, \& Gough, 2008).

Saat ini, banyak anggota organisasi telah bekerja dalam kelompok, tim, atau sebuah komite. Setelah karyawan bekerja sebagai tim dengan tujuan tim yang spesifik, bukan sebagai individu dengan hanya tujuan individu, terbukti dapat meningkatkan level motivasi pegawai. Selanjutnya, kombinasi dari kelompok yang kompatibel dan tujuan individu lebih efektif daripada tujuan individu atau tujuan kelompok saja. Pertimbangan terkait hal terebut adalah bahwa ketika seorang anggota tim merasakan bahwa anggota tim lainnya memiliki tujuan pribadi, individu akan lebih puas dan produktif. Sebuah studi Kristof-Brown dan Stevens (Athanasiades dkk, 2008) menunjukkan bahwa kecocokan yang dirasakan antara individu dan tujuan organisasi menghasilkan kepuasan individu yang lebih besar dan berkontribusi positif dalam pencapaian target organisasi.

Konseling yang berfokus pada penetapan tujuan tidak hanya memberikan pengaruh pada pekerjaan karyawan, tetapi juga mendorong karyawan itu sendiri untuk mencari dan menggunakan metode kerja yang paling efektif dan dengan melibatkan karyawan dalam menetapkan tujuan dapat menumbuhkan motivasi kerja dan prestasi kerja yang maksimal (Steers, Porter, \& Bigley, 1996).

Melalui layanan konseling diharapkan potensi karyawan dapat dikembangkan dan dimanfaatkan secara optimal, iklim kerja yang kondusif dapat diciptakan, serta berbagai perasaan ketidak pastian yang sering manghantui kinerja karyawan dapat diantisipasi dan diatasi (Carrol, 1996). Sumber daya manusia pada bidang industri (di antaranya para karyawan) sebagai human capital perlu ditata pengembangan karirnya, perlu difasilitasi perkembangan potensinya, serta perlu diperhatikan kesejahteraan fisik dan psikhisnya (Walgito, 2005). Layanan konseling di dunia industri diharapkan mampu mengembangkan fungsi-fungsi tersebut.

Gibson, Ivancevich dan Donnely (1996) mengemukakan bahwa motivasi bertalian dengan tiga hal yang sekaligus yang merupakan aspek-aspek dari motivasi. Ketiga hal tersebut adalah keadaan yang mendorong tingkah laku (motivating states), tingkah laku yang didorong oleh keadaan tersebut (motivated behavior), 
dan tujuan dari pada tingkah laku tersebut (goals or ends of such behavior).

Dengan dilaksanakannya konseling kelompok yang berfokus pada penetapan tujuan telah memberikan gambaran dan pemahaman kepada karyawan khususnya kelompok eksperimen mengenai beberapa hal seperti pembelajaran mengenai motivasi dan bagaiman tujuan-tujuan dijabarkan untuk dapat memenuhi harapan mereka terkait dengan tugas dan tanggung jawab dari pekejaan mereka. Peak (Wijono, 2010) mengatakan bahwa dalam membahas mengenai tingkah laku manusia, perlu dipertimbangkan beberapa aspek diantaranya pembelajaran, motivasi, persepsi, sikap dan harapan. Ini berarti motivasi merupakan salah satu sebab penentu tingkah laku manusia, dan tingkah laku dimunculkan oleh faktorfaktor internal dan eksternal. Salah satu faktor internal tersebut adalah motivasi.

Konseling kelompok berfokus pada penetapan tujuan yang telah dilaksanakan memberikan beberapa manfaat pada subjek dan perusahaan. Tujuan dari dilakukannya konseling ini adalah untuk mengetahui sejauh mana konseling berfokus pada penetapan tujuan dapat digunakan untuk meningkatkan motivasi pada karyawan. Berdasarkan hasil analisis di atas peneliti mengambil kesimpulan bahwa konseling kelompok berfokus pada penetapan tujuan dapat meningkatkan motivasi karyawan di PT SM khususnya pada level pengawas. Hal ini membuktikan bahwa konseling kelompok yang berfokus pada penetapan tujuan dapat meningkatkan motivasi karyawan dan dapat dijadikan sebagai salah satu alternatif intervensi yang diberikan untuk dapat meningkatkan motivasi karyawan.

Penelitian yang telah dilakukan ini masih terdapat banyak kelemahan di antaranya instrumen kuesioner yang digunakan dalam penelitian ini seharusnya benar-benar difokuskan pada aspek intrinsik teori motivasi Herzberg yang dijadikan sebagai landasan pembuatan alat ukur. Namun, pada pelaksanaannya masih terdapar beberapa aitem pada alat ukur yang mengungkap aspek yang bersifat ekternal, sehingga hal ini dapat dijadikan masukan pada peneliti selanjutnya yang berminat dengan tema penelitian yang sama.

\section{SIMPULAN DAN SARAN}

\section{Simpulan}

Berdasarkan analisis data dan pembahasan yang dilakukan dalam penelitian ini, maka dapat disimpulkan bahwa konseling kelompok berfokus pada penetapan tujuan dapat meningkatkan motivasi instrinsik karyawan di PT SM. Sedangkan pada kelompok kontrol yang tidak diberikan perlakuan tidak terjadi peningkatan terhadap skor motivasinya dan bahkan cenderung mengalami penurunan. Hal ini membuktikan bahwa konseling kelompok yang berfokus pada penetapan tujuan dapat meningkatkan motivasi karyawan dan dapat dijadikan sebagai salah satu alternatif intervensi yang diberi- 
kan untuk dapat meningkatkan motivasi karyawan.

\section{Saran}

Ada sejumlah saran yang dapat disampaikan. Pertama, saran bagi organisasi. Beberapa di antaranya adalah (1) Perusahaan hendaknya tetap melanjutkan pelaksanaan konseling agar dapat membantu karyawan dalam meningkatkan dan mempertahankan motivasi dan kompetensinya, (2) Perusahaan diharapkan dapat lebih meningkatkan keterlibatan karyawan dalam proses pembuatan perencaan penetapan tujuan dan target pencapaian organisasi, dan (3) Perusahaan memfasilitasi karyawan dengan dengan kegiatankegiatan pengembangan kompetensi lainnya dan disesuaikan dengan kebutuhan yang karyawan itu sendiri.

Kedua, saran bagi peneliti selanjutnya. Beberapa di antaranya adalah (1) Penelitian sejenis sebaiknya juga dilakukan pada perusahaan lain yang berbeda jenis dengan yang peneliti lakukan sebelumnya, karena penelitian dengan tipe perusahaan yang berbeda belum tentu memperoleh hasil yang sama, (2) Penelitian sejenis sebaiknya menambahkan jumlah subjek, aspek-aspek yang ingin diteliti serta metode penggalian informasi yang lebih beragam agar dapat memperoleh hasil yang lebih optimal, (3) Memfokuskan instrumen penelitian hanya pada aspek instrinsik yang menjadi fokus dalam penelitian ini, (4) Dapat memfokuskan dan menggunakan teori motivasi
Islam guna pengembangan psikologi Islam.

\section{DAFTAR PUSTAKA}

Athanasiades C, Winthrop A \& Gough B. (2008). Factors affecting self-referral to counselling services in the workplace (Qualitative Study). British Journal of Guidance \& Counselling, 36 (3), August 2008, 257-276.

Armstrong, M. (2004). Performance Management. (Alih Bahasa: Toni Setiawan). Yogyakarta: Tugu Publisher.

Carroll, M. (1996). Workplace Counselling: A Systematic Approach to Employee Care. London: SAGE Publications Ltd.

Ghozali, I \& Castellan, N.J. (2002). Statistik Nonparametrik: Teori dan Aplikasi dengan Program SPSS. Semarang: Badan Penerbit Universitas Diponegoro.

Gibson, J.L., Ivancevich, J.M., dan Donnelly, J.R., (1996). Organisasi. Edisi Ke-8. (Alih Bahasa: Nunuk Adiarni). Jakarta: Bina Rupa Aksara.

Gomes, F C. (2003). Manajemen Sumber Daya Manusia. Yogyakarta: ANDI. 
Ivanevich, J.M, Konopaske, R, \& Matterson, M.T. (2008). Perilaku dan Manajemen Organisasi. (Alih Bahasa: Gina Gania). Jakarta: Erlangga.

Latipun. (2008). Psikologi Eksperimen: Edisi Pertama. Malang: UMM Pers.

Latipun. (2008). Psikologi Konseling; edisi ketiga. UMM Press: Malang.

Mangkuprawira, S. (2009). Bisnis, Manajemen, dan Sumberdaya Manusia. Bogor: IPB Press.

McLeod, J. (2008). Pengantar Konseling (Teori dan Studi Kasus). Edisi ke-3. (Alih Bahasa; A. K Anwar). Jakarta: Kencana Prenada media Group.

McLeod, J. (2010). The Effectiveness of Workplace Counselling: A systematic review. Counselling and Psychotherapy Research, 10 (4), 238-248.

Robbins, S. P. (2001). Organizational Behaviour, New Jersey: Prentice Hall International Inc.

Robbins, S \& Coulter M. (2009). Manajemen: Edisi 8 / Jilid Pertama. Jakarta: Indeks.

Schein, E. H. (1991). Organizational Culture and Leadership. San Fransisco: Bass Publisher.
Simamora, H. (2006). Manajemen Sumber Daya Manusia: Edisi 2. Yogyakarta: STIE YKPN.

Steers, R.M, Porter, R.W, Bigley G.A (1996). Motivation and Leadership at Work. New York: Mc Graw Hill.

Sugiyono. (2007). Statistik Non Parametris untuk Penelitian. Bandung: Alfabeta.

Sujarwo. (2008). Pengembangan Sumber Daya Manusia Melalui Konseling di Dunia Industri dan Tantangan Globalisasi.

Timpe, A D. (2000). Seri Manajemen Sumber Daya Manusia: Memotivasi Pegawai. (Alih Bahasa: Susanto Budidharmo). Jakarata: Gramedia Pustaka.

Wibowo. (2010). Manajemen Kinerja. Jakarta: PT. Rajagrafindo Persada.

Walgito, B. (2005). Bimbingan dan Konseling (Studi dan Karir). Edisi ke5. Yogyakarta: Andi Offset.

Wardani. E.S. (2009). Pengaruh Kompensasi, Keahlian dan Motivasi Kerja terhadap Prestasi Kerja Karyawan pada PT. Pembangkitan Jawa Bali unit Pembangkit Muara Tawar. (Tesis). Sekolah Pascasarjana Universitas Sumatera Utara. 
Wijayanti. C dan Muhari. (2010). Penerapan Konseling Kelompok Dengan Strategi Self-Management Untuk Mengurangi Kebiasaan Bermain Video Games. Jurnal Psikologi Pendidikan dan Bimbingan, 11 (1), 101-115.

Wijono, S (2010). Psikologi Industri dan Organisasi dalam Suatu Bidang Gerak Psikologi Sumber Daya
Manusia. Jakarta: Kencana Perdana Media Group.

Winardi, J. (2011). Motivasi dan Pemotivasian dalam Manjemen. Jakarta: PT. Raja Grafindo Persada.

Winkel \& Hastuti, S. (2008). Bimbingan dan Konseling Kelompok. Jakarta: Rineka. 